\title{
GMR
}

\section{Changes in gene expression and catalase activity in Oryza sativa L. under abiotic stress}

\author{
I.L. Vighi ${ }^{1}$, L.C. Benitez ${ }^{1}$, M.N. do Amaral ${ }^{1}$, P.A. Auler ${ }^{1}$, G.P. Moraes ${ }^{1}$, \\ G.S. Rodrigues ${ }^{1}$, L.C. da Maia $^{2}$, L.S. Pinto ${ }^{1}$ and E.J.B. Braga ${ }^{1}$ \\ ${ }^{1}$ Departmento de Botânico, Universidade Federal de Pelotas, Pelotas, RS, \\ Brasil \\ ${ }^{2}$ Departamento de Fitotecnia, Universidade Federal de Pelotas, Pelotas, RS, \\ Brasil
}

Corresponding author: E.J.B. Braga

E-mail: jacirabraga@hotmail.com

Genet. Mol. Res. 15 (4): gmr15048977

Received July 18, 2016

Accepted September 19, 2016

Published November 3, 2016

DOI http://dx.doi.org/10.4238/gmr15048977

Copyright $(2016$ The Authors. This is an open-access article distributed under the terms of the Creative Commons Attribution ShareAlike (CC BY-SA) 4.0 License.

\begin{abstract}
Different rice (Oryza sativa L.) genotypes were subjected to high salinity and low temperature $\left(150 \mathrm{mM} \mathrm{NaCl}\right.$ and $13^{\circ} \mathrm{C}$, respectively) for $0,6,24,48$, or $72 \mathrm{~h}$. We evaluated the simultaneous expression of the genes OsCATA, OSCATB, and OsCATC, correlated gene expression with enzyme activity, and verified the regulation of these genes through identification of cis-elements in the promoter region. The hydrogen peroxide content increased in a tolerant genotype and decreased in a sensitive genotype under both stress conditions. Lipid peroxidation increased in the tolerant genotype when exposed to cold, and in the sensitive genotype when exposed to high salinity. Catalase activity significantly increased in both genotypes when subjected to $13^{\circ} \mathrm{C}$. In the tolerant genotype, OsCATA and $O s C A T B$ were the most responsive to high salinity and cold, while in the sensitive genotype, OsCATA and OSCATC responded positively to saline stress,
\end{abstract}


as did OsCATA and OsCATB to low temperature. Cis-element analysis identified different regulatory sequences in the catalase promoter region of each genotype. The sensitive genotype maintained a better balance between hydrogen oxyacid levels, catalase activity, and lipid peroxidation under low temperature than the resistant genotype. OsCATA and $O S C A T B$ were the most responsive in the salt-tolerant genotype to cold, OsCATA and OsCATC were the most responsive to saline stress, and OsCATA and OsCATB were the most responsive to chilling stress in the sensitive genotype. There were positive correlations between catalase activity and $O_{S} C A T B$ expression in the tolerant genotype under saline stress and in the sensitive genotype under cold stress.

Key words: Oryza sativa L.; Salinity; Low temperature; Cis-elements; Reactive oxygen species; Differential expression

\section{INTRODUCTION}

As sessile organisms, plants are constantly exposed to a wide variety of abiotic stressors such as high salinity, water deficit, flooding, and extreme temperatures, which influence growth and development and cause a significant reduction in productivity (Komatsu and Hossain, 2013). Rice (Oryza sativa L.) is one of the most cultivated cereals for food production in the world, and is consumed by over half of the world's population; however, its yield is often reduced by high salinity or low temperatures (Yang et al., 2015). Salt concentrations vary between genotypes, and are related to the ionic composition of the medium. Potentially toxic ions, such as $\mathrm{Na}^{+}$and $\mathrm{Cl}^{-}$, exert a negative effect on the hydrological status of the plant, nutrient absorption, and metabolic pathways, which affects productivity (Munns and Tester, 2008).

In general, the optimum temperature for the culture of rice varies between $25^{\circ}$ and $30^{\circ} \mathrm{C}$, while temperatures lower than $15^{\circ} \mathrm{C}$ damage metabolism, and alter the integrity of membranes and cellular functions (Chinnusamy et al., 2007). Symptoms of phenotypic responses to cold stress include reductions in leaf expansion, wilt, chlorosis, and necrosis (Mahajan and Tuteja, 2005).

Exposure to abiotic stressors such as high salinity and low temperature results in the excessive production of reactive oxygen species (ROS), which are reduced forms of molecular oxygen, such as superoxide anion $\left(\mathrm{O}_{2}^{-*}\right)$, hydrogen peroxide $\left(\mathrm{H}_{2} \mathrm{O}_{2}\right)$, hydroxyl radicals $\left({ }^{\circ} \mathrm{OH}\right)$, and singlet oxygen $\left({ }^{1} \mathrm{O}_{2}\right)$. ROS are present in plant cells as byproducts of normal aerobic metabolism; however, under stress conditions, the balance between ROS production and antioxidant activity is broken in favor of oxidant compounds, which results in oxidative stress (Wang et al., 2010).

Under these conditions, oxidative protection is dependent on antioxidant systems formed by non-enzymatic components, such as ascorbic acid and glutathione, and enzymatic components such as superoxide dismutase (SOD, EC 1.15.1.1), catalase (CAT, EC 1.11.1.6), ascorbate peroxidase (APX, EC 1.1.11.1), glutathione reductase (GR, EC 1.6.4.2), monodehydroascorbate reductase (MDAR, EC 1.6.5.4), and dehydroascorbate reductase (DHAR, EC 1.8.5.1) (Ashraf, 2009).

CAT $\left(\mathrm{H}_{2} \mathrm{O}_{2}: \mathrm{H}_{2} \mathrm{O}_{2}\right)$ is a potent antioxidant, the expression of which varies with stress intensity. It plays a central role in protecting plants against a variety of environmental stressors.

Genetics and Molecular Research 15 (4): gmr15048977 
CAT is found in all aerobic organisms, and catalyzes the conversion of two molecules of $\mathrm{H}_{2} \mathrm{O}_{2}$ and $\mathrm{O}_{2}$ in water through the transfer of two electrons in peroxisomes and glyoxysomes (Zeng et al., 2010). $\mathrm{H}_{2} \mathrm{O}_{2}$ formed in these organelles can originate during the $\beta$-oxidation of fatty acids, photorespiration, and purine catabolism (Gill and Tuteja, 2010). Different CAT isoforms in rice are coded by the genes OsCATA, OsCATB, and OsCATC. Several studies have investigated the expression, cloning, and characterization of these genes under stress in rice and other species (Khare et al., 2015; Chakraborty and Bhattacharjee, 2015).

In adverse conditions, the expression of a variety of genes is induced, and their products not only act directly but also by regulating the expression of other genes, and in the transduction of response signals to stress. Gene expression is regulated by a complex molecular network, and important components of this network are transcription factors, which bind to specific DNA substances known as cis-elements. Such sequences, located in the promoter region of the genes, act in the activation or repression of transcription, and each gene has a combination of cis-single elements, causing the control of temporal and spatial transcription to be specific (Qiu, 2003). The presence of these elements as regulators may determine the responses of plants facing stressful conditions.

Therefore, the objective of this study was to evaluate the following in two rice genotypes ('BRS Pampa' and 'BRS Bojuru') under salt and temperature stress: i) the expression patterns of genes that encode CAT, and their relationship with enzymatic activity; and ii) the cis-elements present in the promoter region that may affect the transcriptional responses of OsCATA, OsCATB, and OsCATC.

Although several studies have been conducted on the role of CAT in response to abiotic stress, the present study investigated the simultaneous expression of all the genes, rather than that of single genes, correlated gene expression with enzyme activity (final product), and verified the regulation of these genes through the identification of regulatory elements.

\section{MATERIAL AND METHODS}

\section{Plant material and stress conditions}

The experiments were conducted with two rice genotypes that have contrasting responses to stress caused by high salinity and low temperature: 'BRS Pampa' (subspecies indica, sensitive) and 'BRS Bojuru' (subspecies japonica, tolerant).

The seeds were germinated in a roll of germitest paper at $25^{\circ} \pm 2^{\circ} \mathrm{C}$ for 10 days in an acclimatized germination chamber (Solab Cientifica, Brazil). After this period, the plantlets were transferred to a floating hydroponic growing system in a greenhouse at $28^{\circ} \pm$ $2^{\circ} \mathrm{C}$, which consisted of trays containing $20 \mathrm{~L}$ nutritive solution (Yoshida et al., 1976). The plants were cultivated under these conditions until they had four leaves (V4 vegetative stage). Subsequently, to simulate saline stress, $150 \mathrm{mM} \mathrm{NaCl}$ was added to the nutrient solution (Singh et al., 2010). To simulate the stress caused by low temperature, plants in the control treatment were removed, and the remaining trays were transferred to a growth chamber with a temperature of $13^{\circ} \mathrm{C}$, where they remained for $72 \mathrm{~h}$. For both treatments, three trays/genotypes with 50 seedlings were used, each being a biological replicate.

Leaves were collected for analysis after 0 (control), 6, 24, 48, and $72 \mathrm{~h}$ of stress. The experimental design was completely randomized in a factorial $2 \times 5$ arrangement (two genotypes $\mathrm{x}$ five time points), with three repetitions per treatment.

Genetics and Molecular Research 15 (4): gmr15048977 


\section{Determination of $\mathrm{H}_{2} \mathrm{O}_{2}$ and lipid peroxidation}

The $\mathrm{H}_{2} \mathrm{O}_{2}$ concentration was determined according to Velikova et al. (2000). Leaf samples $(200 \mathrm{mg})$ were macerated and homogenized in $2.0 \mathrm{~mL}$ trichloroacetic acid (TCA) $(0.1 \%$ $\mathrm{m} / \mathrm{v}$ ) and centrifuged (Refrigerated Centrifuge TGL-16M - Genorise Scientific, Inc., Paoli, IN, USA) at $12,000 \mathrm{~g}$ for $15 \mathrm{~min}$. Then, $0.8 \mathrm{~mL} 10 \mathrm{mM}$ potassium phosphate buffer, $\mathrm{pH} 7.0$, and $1.0 \mathrm{~mL} 1 \mathrm{M}$ potassium iodide were added to the supernatant. Spectrophotometer -Ultrospec ${ }^{\mathrm{TM}}$ 7000 - GE Healthcare (Little Chalfont, UK) measurements were taken at $390 \mathrm{~nm}$, and the $\mathrm{H}_{2} \mathrm{O}_{2}$ concentration was calculated by comparing the readings with the standard curve obtained from different concentrations of $\mathrm{H}_{2} \mathrm{O}_{2}$, and was expressed in $\mu \mathrm{M} \mathrm{H}_{2} \mathrm{O}_{2} / \mathrm{g}$ (fresh weight).

Lipid peroxidation was determined by estimating the malondialdehyde (MDA) content according to the method of Heath and Packer (1968). Approximately $200 \mathrm{mg}$ leaf samples were macerated and homogenized in $2.0 \mathrm{~mL} \mathrm{TCA}(0.1 \% \mathrm{~m} / \mathrm{v})$ and centrifuged at $12,000 \mathrm{~g}$ for $15 \mathrm{~min}$. Then, thiobarbituric acid (TBA) $(0.5 \% \mathrm{~m} / \mathrm{v})$ and TCA $(10 \% \mathrm{~m} / \mathrm{v})$ were added to the supernatant, which was subsequently heated in a water bath at $95^{\circ} \mathrm{C}$ for $30 \mathrm{~min}$. The reaction was terminated by cooling in an ice bath for $10 \mathrm{~min}$. TBA absorbance was determined at 535 and $600 \mathrm{~nm}$, and the concentration of the MDA-TBA complex was calculated by the equation $\operatorname{MDA}=\left(\mathrm{A}_{535}-\mathrm{A}_{600}\right) /(\xi . \mathrm{b})$, where $\xi$ is the extinction coefficient $\left(=1.56 \times 10^{-5} \mathrm{~cm}^{-1}\right)$, and $\mathrm{b}$ is the optical length (1). Lipid peroxidation is expressed in $\mathrm{nmol} \mathrm{MDA} / \mathrm{g}$ fresh weight.

\section{Enzymatic extract preparation, determination of total proteins, and CAT activity}

For preparation of the enzymatic extract, $200 \mathrm{mg}$ leaf tissue was macerated with $\mathrm{N}_{2}$ liquid and homogenized in $2.0 \mathrm{~mL}$ extraction buffer composed of $100 \mathrm{mM}$ potassium phosphate, $\mathrm{pH}$ 7.0, $0.1 \mathrm{mM}$ ethylenediaminetetraacetic acid, and $10 \mathrm{mM}$ ascorbic acid. The homogenate was centrifuged at $13,000 \mathrm{~g}$ for $15 \mathrm{~min}$ at $4^{\circ} \mathrm{C}$.

Protein quantification was conducted according to the methodology described by Bradford (1976). Readings were taken at $595 \mathrm{~nm}$ and compared with the standard curve of $0.1 \mathrm{~g} / \mathrm{L}$ bovine serum albumin. Protein content is expressed as $\mathrm{mg}$ protein $/ \mathrm{mg}$ fresh weight. The determination of CAT activity (EC 1.11.1.6) was performed as described by Azevedo et al. (1998), and was based on the consumption of $\mathrm{H}_{2} \mathrm{O}_{2}$ (extinction coefficient, $39.4 \mathrm{mM} /$ $\mathrm{cm}$ ). The reaction medium was composed of potassium $100 \mathrm{mM}$ phosphate buffer, $\mathrm{pH}$ 7.0, $12.5 \mathrm{mM} \mathrm{H}_{2} \mathrm{O}_{2}$, water, and the enzymatic extract. CAT activity was identified by a decrease in absorbance at $240 \mathrm{~nm}$ for $2 \mathrm{~min}$, and is expressed as $\mathrm{mmol} \mathrm{H}_{2} \mathrm{O}_{2} \cdot \mathrm{min}^{-1} \mathrm{xmg}^{-1}$ protein.

\section{Statistical analysis}

The data were submitted to analysis of variance $(\mathrm{P} \leq 0.05)$ to identify the sources of variation and their possible interactions. The averages were compared by the Tukey test at the $5 \%$ probability level using the statistical software SAS 9.3 (SAS Institute, Cary, NC, USA).

\section{RNA extraction, cDNA synthesis, and primer design}

Total RNA was extracted from $0.1 \mathrm{~g}$ leaves using PureLink ${ }^{\circledR}$ reagent (Invitrogen ${ }^{\mathrm{TM}}$ ). In order to degrade DNA contaminants, the samples were treated with DNase I (Invitrogen ${ }^{\mathrm{TM}}$ ). The quality, quantity, and purity of the total RNA were evaluated by electrophoresis on $1 \%$

Genetics and Molecular Research 15 (4): gmr15048977 
agarose gel and with a NanoDrop ${ }^{\circledR}$ ND-1000 (Waltham, MA, EUA). Each sample was reversely transcribed into cDNA using a SuperScript ${ }^{\mathrm{TM}}$ First-Strand Synthesis System for RT-PCR Kit (Invitrogen ${ }^{\mathrm{TM}}$ ). Primers were designed for OsCATA, OsCATB, and OsCATC using sequences deposited in the RAP-DB database (http://rapdb.dna.affrc.go.jp/) and the program PerlPrimer v.1.1.21. As an internal control, we used the gene $U B Q 10$, which has previously been tested for these experimental conditions (Moraes et al., 2015). Only initiators that had a dissociation curve with a single peak and an amplification efficiency close to $100 \%(E=1.8-2.2)$ were used (Table 1).

\begin{tabular}{|c|c|c|}
\hline Gene & Locus & Sense/antisense* \\
\hline$\overline{O S C A T A}$ & AK065094.1 & $\begin{array}{l}\text { 5'GTGAAGATTGCGAATAGGCTC3' } \\
\text { 5'TCTGGCCTTATTTGGTTGGT3' }\end{array}$ \\
\hline OSCATB & AK100019.1 & $\begin{array}{l}\text { 5'GACAAGGAGAACAATTTCCAACAG3' } \\
\text { 5'AGTAGGAGATCCAGATGCCAC3' }\end{array}$ \\
\hline$\overline{O S C A T C}$ & AK066378.1 & $\begin{array}{l}\text { 5'GTGATTGCCAAGGAGAACAAC3' } \\
\text { 5'GAGTGCGTCGATCCATCTCT3' }\end{array}$ \\
\hline$U B Q 10$ & AK101547 & $\begin{array}{l}\text { 5'TGGTCAGTAATCAGCCAGTTTGG3' } \\
\text { 5'GCACCACAAATACTTGACGAACAG3' }\end{array}$ \\
\hline OSCATA & Upstream 1 & $\begin{array}{l}\text { 5'AGCAGCAGGTATCTGGGAG3' } \\
\text { 5'AAACTTTGGCCGACCGAT3' }\end{array}$ \\
\hline \multirow[t]{2}{*}{ OSCATA } & \multirow[t]{2}{*}{ Upstream 2} & 5'CCTTTCTCTTGATCGGTCGG3' \\
\hline & & 5'CTCTGCAACGGACGGATT3' \\
\hline OSCATA & Upstream 3 & $\begin{array}{l}\text { 5'AAATCCGTCCGTTGCAGAG3' } \\
\text { 5'GCTGCTTCGATCTTCCATCAC3' }\end{array}$ \\
\hline$\overline{O S C A T B}$ & Upstream 1 & 5'ATGGAGGGAGTATGTTGTTGGT3' \\
\hline OSCATB & Upstream 2 & $\begin{array}{l}5^{\prime} \text { CACTGCTATACTACACGACGAC3' } \\
5^{\prime} \text { CAGAGACTGGGAAATCAGGAAT3' }\end{array}$ \\
\hline OsCATB & Upstream 3 & 5'CGGATTCCTGATTTCCCAGTC 3' \\
\hline \multirow[t]{2}{*}{ OsCATC } & \multirow[t]{2}{*}{ Upstream 1} & $\begin{array}{l}\text { 5'CGTGCTAGTATGCTTCTTGCC3' } \\
\text { 5'TCTTTCCGGGCTCAAATGATG3' } \\
\end{array}$ \\
\hline & & 5'ACCAATACTGTCTCAACTGGCT3' \\
\hline \multirow[t]{2}{*}{ OsCATC } & \multirow[t]{2}{*}{ Upstream 2} & 5'AGATGCTGTTCACATTGACCC3' \\
\hline & & 5'TGAAAGATGGAAGGTGGTTGG3' \\
\hline \multirow[t]{2}{*}{$\overline{O S C A T C}$} & \multirow[t]{2}{*}{ Upstream 3} & 5'CCTGATATGACAAAGGTAGCCA3' \\
\hline & & 5'CTGTTGTGATCGAAGATGTCCT3' \\
\hline
\end{tabular}

*The annealing temperature was $61^{\circ} \mathrm{C}$.

\section{Reverse transcription-quantitative polymerase chain reaction (RT-qPCR)}

The total volume of the reaction was $12 \mu \mathrm{L}$, which contained $6.25 \mu \mathrm{L}$ FastStart Universal SYBR ${ }^{\circledR}$ Green Master (Roche), $0.25 \mu \mathrm{L} 10 \mathrm{mM}$ of each primer (sense and antisense), $1 \mu \mathrm{L}$ cDNA (dilution 1:5, as previously described), and $4.25 \mu \mathrm{L}$ ultra-pure water. The reactions were performed in a Bio-Rad CFX Real-Time thermocycler, under the following conditions for the amplification: $95^{\circ} \mathrm{C}$ for $10 \mathrm{~min}, 40$ cycles of $95^{\circ} \mathrm{C}$ for $15 \mathrm{~s}$, and $60^{\circ} \mathrm{C}$ for 1 min with insertion of the melting curve at $65^{\circ}$ to $95^{\circ} \mathrm{C}$, with increments of $5^{\circ} \mathrm{C}$ to each fluorescence measurement. Quantification of the relative expression of each gene was performed as described by Livak and Schmittgen (2001).

\section{Correlation analysis}

To measure the strength of the correlation between the expression of CAT-encoding 
genes and enzymatic activity, Pearson's correlation coefficients were calculated for each genotype within each stress treatment, and were graphically represented by heat maps. The analyses were conducted using the SAS software v.9.3 (SAS Institute Inc.) using the proccorr and procsgrender routines.

\section{Sequencing and analysis of the promoter region}

We selected $1200 \mathrm{bp}$ from the promoter regions of each CAT-homologous gene (OsCATA, OsCATB, and OsCATC) from sequences deposited in the RAP-DB database. Three pairs of primers were designed for each promoter region using the primer amplification system, Primer Walking, in which each of the resultant amplicons contained approximately $450 \mathrm{bp}$. DNA extraction was performed according to Weising et al. (2005). The quality and quantity of the DNA extracted from the samples was verified on $0.8 \%$ agarose gel using the molecular weight marker, Lambda DNA/HindIII.

PCRs were performed in triplicate, and each contained a total volume of $20 \mu \mathrm{L}$. The cycling conditions consisted of denaturation at $94^{\circ} \mathrm{C}(4 \mathrm{~min})$; followed by 40 cycles at $94^{\circ} \mathrm{C}$ $(40 \mathrm{~s}), 65^{\circ} \mathrm{C}(40 \mathrm{~s}), 72^{\circ} \mathrm{C}(2 \mathrm{~min} 30 \mathrm{~s})$; and a final extension at $72^{\circ} \mathrm{C}(7 \mathrm{~min})$. The amplified products were separated by electrophoresis on $1.5 \%$ agarose gel, stained with ethidium bromide, and observed under ultraviolet light.

Purification of the PCR products was performed using a Wizard ${ }^{\circledR}$ Genomic DNA Purification Kit (Promega), following the manufacturer guidelines. Once purified, the DNA samples were sent for sequencing by ACT Gene Análises Moleculares (http://ludwigbiotec. com.br/site/Servicos-de-Sequenciamento), who used an ABI-Prism 3500 Genetic Analyzer (Applied Biosystems). Sequencing reactions were performed using sense and antisense primers (Table 1).

For the sequence analysis, we used the CodonCode Aligner program (http://www. codoncode.com/aligner/), which cleaned and assembled the contigs. Subsequently, contigs were aligned by BLASTn (https://blast.ncbi.nlm.nih.gov/Blast.cgi?PAGE_TYPE=BlastSearch), using promoters of the 'Nipponbare' genotype as a template. Cis-elements were identified using the program PLANTCIS (http://Microsatellite.org/cis_input.html). Cis-elements with a value of $Z \leq 5$ were considered significant.

\section{RESULTS}

\section{$\mathrm{H}_{2} \mathrm{O}_{2}$ content, lipid peroxidation, and CAT activity}

Analysis of variance revealed a significant interaction between the factors (genotype $\mathrm{x}$ period of stress) on the $\mathrm{H}_{2} \mathrm{O}_{2}$ content, lipid peroxidation (MDA), and CAT activity, under both saline and low temperature stress.

The $\mathrm{H}_{2} \mathrm{O}_{2}$ content of 'BRS Bojuru' (tolerant) increased throughout the time of exposure to stress, with a two-fold increase after $72 \mathrm{~h}$ compared to the control, both in conditions of low temperature and high salinity (Table 2). For 'BRS Pampa' (sensitive), a similar response was observed under the two experimental conditions and there was a decrease in the $\mathrm{H}_{2} \mathrm{O}_{2}$ content, with the highest value observed in control plants, which only differed after $24 \mathrm{~h}$ under both conditions. In genotypes, was no statistical difference in the control treatment in both experiments, and only in $72 \mathrm{~h}$ for the cold (Table 2).

Genetics and Molecular Research 15 (4): gmr15048977 
Table 2. Hydrogen peroxide content of 'BRS Bojuru' and 'BRS Pampa' leaves under high salinity (150 mM $\mathrm{NaCl})$ and low temperature $\left(13^{\circ} \mathrm{C}\right)$ at different time points.

\begin{tabular}{|c|c|c|c|c|c|}
\hline \multirow[t]{2}{*}{ Genotype } & \multicolumn{5}{|c|}{ Period under high salinity (h) } \\
\hline & 0 & 6 & 24 & 48 & 72 \\
\hline BRS Bojuru & $0.30 \pm 0.02^{\mathrm{Bb} *}$ & $0.37 \pm 0.03^{\mathrm{Ba}}$ & $0.38 \pm 0.04^{\mathrm{Ba}}$ & $0.56 \pm 0.02^{\mathrm{Aa}}$ & $0.60 \pm 0.04^{\mathrm{Aa}}$ \\
\hline \multirow[t]{3}{*}{ BRS Pampa } & $0.57 \pm 0.02^{\mathrm{Aa}}$ & $0.47 \pm 0.05^{\mathrm{Aa}}$ & $0.37 \pm 0.02^{\mathrm{Ba}}$ & $0.53 \pm 0.05^{\mathrm{Aa}}$ & $0.52 \pm 0.06^{\mathrm{Aa}}$ \\
\hline & \multicolumn{5}{|c|}{ Period under low temperature (h) } \\
\hline & 0 & 6 & 24 & 48 & 72 \\
\hline BRS Bojuru & $0.38 \pm 0.03^{\mathrm{Bb} *}$ & $0.51 \pm 0.04^{\mathrm{Aa}}$ & $0.32 \pm 0.08^{\mathrm{Ba}}$ & $0.56 \pm 0.02^{\mathrm{Aa}}$ & $0.60 \pm 0.04^{\mathrm{Aa}}$ \\
\hline BRS Pampa & $0.53 \pm 0.06^{\mathrm{Aa}}$ & $0.42 \pm 0.06^{\mathrm{Aa}}$ & $0.32 \pm 0.03^{\mathrm{Ba}}$ & $0.48 \pm 0.08^{\mathrm{Aa}}$ & $0.47 \pm 0.09^{\mathrm{Ab}}$ \\
\hline
\end{tabular}

*Values are reported as the average of each treatment $\pm \mathrm{SD}(\mathrm{N}=3)$. Averages followed by the same capital letter did not significantly differ in stress time for each genotype and averages followed by the same lowercase letter did not differ the genotypes within each stress time according to the Tukey test at $5 \%$ probability.

'BRS Bojuru' exhibited a significant decrease in MDA levels at all time points under saline stress, whereas in 'BRS Pampa', MDA levels had increased after $24 \mathrm{~h}$ and increased by 2.08 -fold after $72 \mathrm{~h}$. 'BRS Bojuru' had lower lipid peroxidation levels than 'BRS Pampa', regardless of the time of exposure to high salinity (Table 3). At low temperature, the opposite was observed, with MDA increasing at all time points in 'BRS Bojuru', but significantly decreasing in 'BRS Pampa' after $48 \mathrm{~h}$ compared to the control (Table 3).

Table 3. Levels of lipid peroxidation (malondialdehyde) in 'BRS Bojuru' and 'BRS Pampa' leaves under high salinity $(150 \mathrm{mM} \mathrm{NaCl})$ and low temperature $\left(13^{\circ} \mathrm{C}\right)$ at different time points.

\begin{tabular}{l|c|c|c|c|c}
\hline \multirow{2}{*}{ Genotype } & \multicolumn{5}{|c}{ Period under high salinity (h) } \\
\cline { 2 - 6 } & 0 & 6 & 24 & 48 & 72 \\
\hline BRS Bojuru & $34.4 \pm 1.44^{\mathrm{Aa} *}$ & $22.0 \pm 1.94^{\mathrm{Ba}}$ & $23.2 \pm 0.52^{\mathrm{Bb}}$ & $21.5 \pm 1.39^{\mathrm{Bb}}$ & $16.9 \pm 1.09^{\mathrm{Cb}}$ \\
\hline \multirow{2}{*}{ BRS Pampa } & $38.6 \pm 1.25^{\mathrm{Ca}}$ & $27.9 \pm 0.51^{\mathrm{Da}}$ & $41.7 \pm 1.49^{\mathrm{Ca}}$ & $72.3 \pm 1.10^{\mathrm{Ba}}$ & $80.6 \pm 1.06^{\mathrm{Aa}}$ \\
\hline & \multicolumn{5}{|c|}{ Period under low temperature (h) } \\
\cline { 2 - 7 } & 0 & 6 & 24 & 37 & $31.3 \pm 1.93^{\mathrm{Bb}}$ \\
\hline BRS Bojuru & $19.4 \pm 1.91^{\mathrm{Cb} *}$ & $20.0 \pm 1.21^{\mathrm{Cb}}$ & $51.0 \pm 1.15 \mathrm{Aa}$ & $37.6 \pm 2.16^{\mathrm{Ba}}$ & $49.0 \pm 1.43^{\mathrm{Aa}}$ \\
\hline BRS Pampa & $48.6 \pm 2.47^{\mathrm{Aa}}$ & $50.3 \pm 2.26^{\mathrm{Aa}}$ & $41.7 \pm 2.91 \mathrm{Aa}$ & $36.7 \pm 1.51^{\mathrm{Ba}}$ & 4 \\
\hline
\end{tabular}

*Values are reported as the average of each treatment $\pm \mathrm{SD}(\mathrm{N}=3)$. Averages followed by the same capital letter did not significantly differ in stress period for each genotype and averages followed by the same lowercase letter did not differ from the genotypes within each stress time according to the Tukey test at $5 \%$ probability.

Under salt stress, CAT activity was stable throughout the evaluation time in both genotypes evaluated. 'BRS Pampa' had significantly higher CAT levels at 6 and $48 \mathrm{~h}$ of stress than 'BRS Bojuru' (Table 4). Under low temperature stress, CAT activity increased after $6 \mathrm{~h}$ of stress in both genotypes. In 'BRS Bojuru', the highest CAT activity was observed up to 24 $\mathrm{h}$, followed by a decrease; however, all the values were higher than those in the control. There was a significant difference in CAT activity at $6 \mathrm{~h}$ between 'BRS Pampa' and the control. There was only a significant difference between the genotypes after $6 \mathrm{~h}$ of cold exposure (Table 4 ).

\section{Gene expression encoders of CAT}

The relative expression data obtained under saline stress indicated that OsCATA and OSCATB were the most responsive to this condition in the tolerant genotype. For OsCATA, the levels of expression were 6.65 and 3.03 times higher than in the control group at 6 and $24 \mathrm{~h}$ of treatment, respectively. For $O S C A T B$, the maximum level of transcripts (relative quantification, $\mathrm{RQ})$ was observed at $6 \mathrm{~h}$ of stress $(\mathrm{RQ}=2.82)$, accompanied by a decrease to similar levels

Genetics and Molecular Research 15 (4): gmr15048977 
as the control at $72 \mathrm{~h}(\mathrm{RQ}=1.11)$ (Figure 1A). In the sensitive genotype, the maximum level of OsCATA transcripts was observed at $24 \mathrm{~h}$ of exposure to salt $(\mathrm{RQ}=17.23)$. Contrary to that observed in 'BRS Bojuru', OsCATC expression in the sensitive genotype was above that in the control at all time points, with the highest values at $24 \mathrm{~h}(\mathrm{RQ}=10.12)$ and $48 \mathrm{~h}(\mathrm{RQ}=12.12)$ (Figure 1B). However, OsCATB had similar levels of expression in 'BRS Bojuru' and 'BRS Pampa' (Figure 1A and B).

Table 4. Catalase activity in 'BRS Bojuru' and 'BRS Pampa' leaves under high salinity $(150 \mathrm{mM} \mathrm{NaCl})$ and low temperature $\left(13^{\circ} \mathrm{C}\right)$ at different time points.

\begin{tabular}{l|c|c|c|c|c}
\hline \multirow{2}{*}{ Genotype } & \multicolumn{5}{|c}{ Period under high salinity (h) } \\
\cline { 2 - 6 } & 0 & 6 & 24 & 48 & 72 \\
\hline BRS Bojuru & $0.16 \pm 0.01^{\mathrm{Aa} *}$ & $0.14 \pm 0.02^{\mathrm{Ab}}$ & $0.15 \pm 0.04^{\mathrm{Aa}}$ & $0.13 \pm 0.01^{\mathrm{Ab}}$ & $0.18 \pm 0.04^{\mathrm{Aa}}$ \\
\hline BRS Pampa & $0.17 \pm 0.01^{\mathrm{Aa}}$ & $0.19 \pm 0.02^{\mathrm{Aa}}$ & $0.15 \pm 0.02^{\mathrm{Aa}}$ & $0.17 \pm 0.02^{\mathrm{Aa}}$ & $0.15 \pm 0.01^{\mathrm{Aa}}$ \\
\hline & 0 & 6 & 24 & 48 & 72 \\
\cline { 2 - 6 } & $0.05 \pm 0.010^{\mathrm{Ba}} *$ & $0.10 \pm 0.008^{\mathrm{Ab}}$ & $0.12 \pm 0.011^{\mathrm{Aa}}$ & $0.09 \pm 0.012^{\mathrm{ABa}}$ & $0.08 \pm 0.007^{\mathrm{ABa}}$ \\
\hline BRS Bojuru & $0.050^{\mathrm{Ba}}$ & $0.09 \pm 0.010^{\mathrm{Ba}}$ & $0.11 \pm 0.012^{\mathrm{ABa}}$ \\
\hline BRS Pampa & $0.08 \pm 0.012^{\mathrm{Ba}}$ & $0.15 \pm 0.009^{\mathrm{Aa}}$ & $0.09 \pm 0.012^{\mathrm{Ba}}$ & 0.09 under low temperature $(\mathrm{h})$ \\
\hline
\end{tabular}

*Values are reported as the average of each treatment $\pm \mathrm{SD}(\mathrm{N}=3)$. Averages followed by the same capital letter did not significantly differ in stress period for each genotype and averages followed by the same lowercase letter did not differ from the genotypes within each stress time according to the Tukey test at $5 \%$ probability.
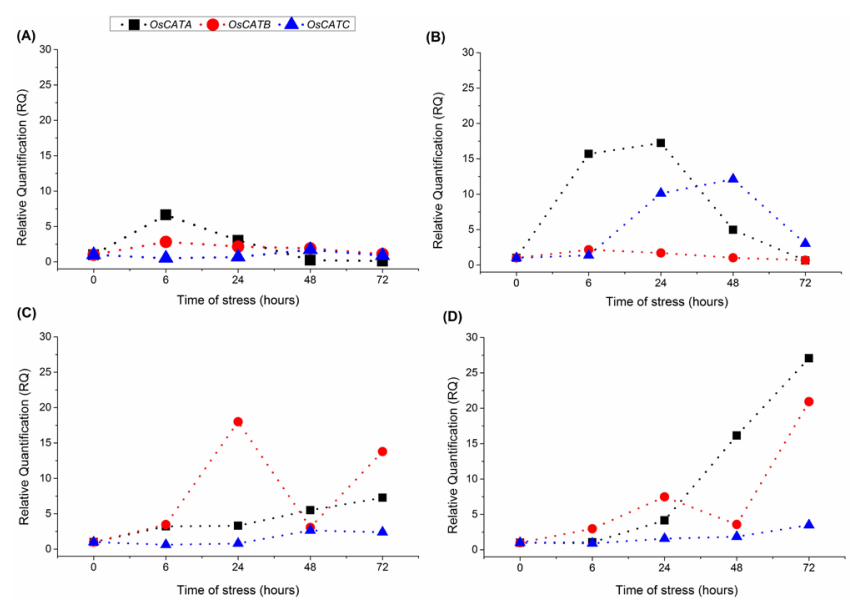

Figure 1. Relative quantification of the expression of encoding genes for catalase in 'BRS Bojuru' and 'BRS Pampa' leaves under high salinity $(150 \mathrm{mM} \mathrm{NaCl})\left(\mathbf{A}\right.$ and $\mathbf{B}$, respectively) and low temperature $\left(13^{\circ} \mathrm{C}\right)(\mathbf{C}$ and $\mathbf{D}$, respectively) at different time points.

Under low temperature, the expression levels of all three CAT genes in both genotypes were above those in the control. OsCATA expression levels increased during the treatment, with maximum values at $72 \mathrm{~h}(\mathrm{RQ}=7.26$ and 27.06 for the tolerant and sensitive genotypes, respectively). OsCATB was more induced by low temperature than high salinity in both genotypes, with an increase in expression until $24 \mathrm{~h}$ followed by a decrease to $48 \mathrm{~h}$, and another increase at the final time point. Although $O S C A T C$ expression levels were higher than those in the control and in most of the treatments, they were lower than those of OSCATA and OSCATB; therefore, OSCATC was the least responsive to low temperature in both genotypes (Figure $1 \mathrm{C}$ and $\mathrm{D}$ ). 


\section{Correlation analysis}

Under salt stress, the correlation coefficients ranged from -0.79 to 0.85 between the variables analyzed for 'BRS Bojuru', and from -0.88 to 0.92 for 'BRS Pampa' (Figure 2A and B). A negative correlation was found between CAT activity and the other variables in the tolerant genotype, except between CAT activity and $\mathrm{H}_{2} \mathrm{O}_{2}$ content, which had a non-significant, positive correlation (0.17).

Correlations between CAT activity and the expression levels of genes that encode this protein were negative. However, OsCATA and OsCATB expression levels were positively correlated (0.85), i.e., in conditions of high salinity, OsCATA expression increased in parallel to increases in $O S C A T B$ expression. However, both genes were negatively correlated with OsCATC (Figure 2A). Contrasting responses were observed in the sensitive genotype, in which we found positive correlations between CAT activity and $\mathrm{H}_{2} \mathrm{O}_{2}$ content $(0.36)$ and CAT activity and $O S C A T B(0.33)$. The strongest correlation was between OsCATA and OSCATB expression levels (0.92), and the lowest between OsCATB and OsCATC expression levels (-0.05) (Figure 2B). Under low temperature, the correlation coefficients ranged from -0.94 to 0.80 between the variables analyzed for 'BRS Bojuru', and from -0.33 to 0.96 for 'BRS Pampa'. In the tolerant genotype, the correlation coefficients between CAT activity and the other variables ranged between -0.94 (CAT activity and $\mathrm{H}_{2} \mathrm{O}_{2}$ content) and 0.70 (CAT activity and MDA), and OsCATB expression was the most correlated with enzyme activity (0.61). OsCATA expression was highly, positively correlated with $O S C A T C$ expression $(0.80)$, followed by OSCATB (0.40). No correlation was found between $O s C A T B$ and OsCATC expression (Figure 3A). In the sensitive genotype, CAT activity was most correlated with MDA level (0.53), and least correlated with $\mathrm{H}_{2} \mathrm{O}_{2}$ content (-0.33). The expression levels of all of the genes were positively correlated with coefficients close to 1.00; however, no correlation was observed between CAT activity and gene expression (Figure 3B).

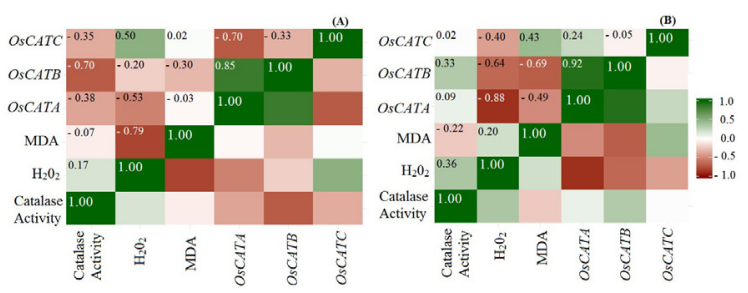

Figure 2. Pearson correlation analysis among variables in 'BRS Bojuru' (A) and 'BRS Pampa' (B) under high salinity $(150 \mathrm{mM} \mathrm{NaCl}) . \mathrm{H}_{2} \mathrm{O}_{2}$, hydrogen peroxide; $\mathrm{MDA}$, malondialdehyde (lipid peroxidation).

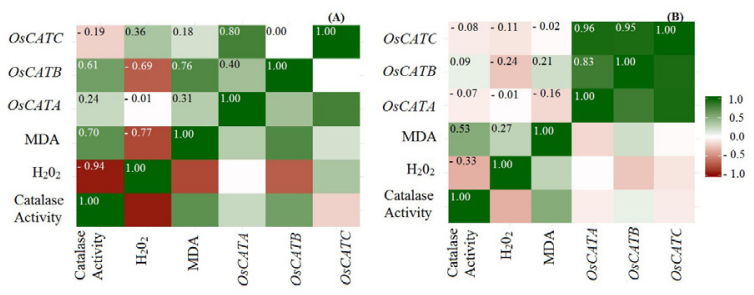

Figure 3. Pearson correlation analysis among variables in 'BRS Bojuru' (A) and 'BRS Pampa' (B) under low temperature $\left(13^{\circ} \mathrm{C}\right) \cdot \mathrm{H}_{2} \mathrm{O}_{2}$, hydrogen peroxide; MDA, malondialdehyde (lipid peroxidation).

Genetics and Molecular Research 15 (4): gmr15048977 


\section{Analysis of cis-elements}

In 'BRS Bojuru', 120 cis-elements were found (Figure 4A), 16 of which were only observed in the OsCATA promoterregion, includingABRERATCAL,ANAERO2CONSENSUS, ANAERO3CONSENSUS, CAREOSREP1, DRECRTCOREAT, and TATABOXOSPAL. Ten were found in $O S C A T B$, including ACGTABOX and ACGTOSGLUB1, and 22 were specific to OsCATC, including AMYBOX1, GARE1OSREP1, MYCATRD22, TATCCAOSAMY, and TATCCAYMOTIFOSRAMY3D. Thirty-six cis-elements were common to the promoter regions of all three genes, which probably had similar expression levels. All cis-elements identified in the three genes in 'BRS Bojuru' are listed in Table S1.

In 'BRS Pampa', 112 cis-elements were found (Figure 4B), seven of which were identified only in the OSCATA promoter region, including ANAERO3CONSENSUS and IBOXCORENT. Fifteen were found in OSCATB, including ABREOSRAB21, ABRERATCAL, and CGACGOSAMY3, and 25 were found in OSCATC, including ANAERO2CONSENSUS, E2FCONSENSUS, MYCATRD22, PREATPRODH, PROLAMINBOXOSGLUB1, and WUSATA. All of the cis-elements identified in the three genes in 'BRS Pampa' are listed in Table S2.

A total of 48,57 , and $61 \%$ of the cis-elements found in the promoter regions of OsCATA, OsCATB, and OSCATC, respectively, were common to both genotypes. However, 'BRS Bojuru' had a higher number of cis-elements in OsCATA and OsCATB than 'BRS Pampa', while 'BRS Pampa' had a greater number of cis-elements in OsCATC than 'BRS Bojuru' (Figure 5).
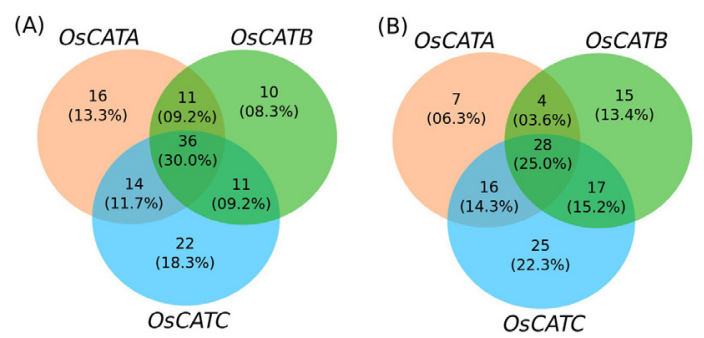

Figure 4. Venn diagram illustrating the distribution of cis-elements in the promoter regions (1200 bp) of OsCATA, OsCATB, and OsCATC in 'BRS Bojuru' (A) and 'BRS Pampa' (B).

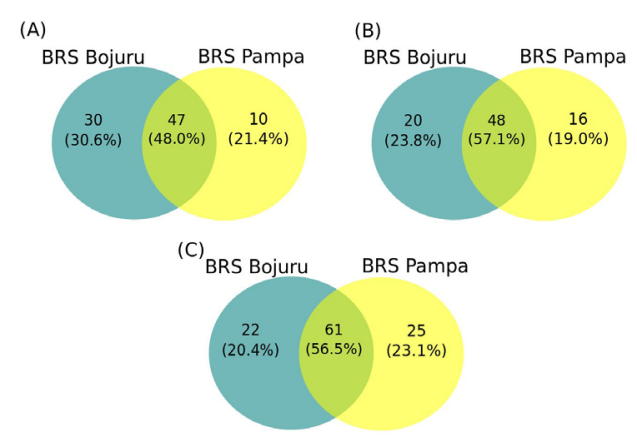

Figure 5. Venn diagram comparing the number of cis-elements identified in the promoter regions (1200 bp) of OsCATA (A), OsCATB (B), and OsCATC (C) in 'BRS Bojuru' and 'BRS Pampa'. 


\section{DISCUSSION}

ROS that are induced by stress, such as $\mathrm{H}_{2} \mathrm{O}_{2}$, can cause damage to cell membranes, protein degradation, double-strand DNA breakage, lipid peroxidation, and cell death. However, the intensity of oxidative damage may vary depending on how rapidly the activity of enzymes such as CAT, APX, and GR confer oxidative protection (Munns and Tester, 2008). In our study, although the $\mathrm{H}_{2} \mathrm{O}_{2}$ content increased, levels of lipid peroxidation decreased under saline stress, and there was little change in CAT activity in the tolerant genotype (Tables 2, 3, and 4). $\mathrm{H}_{2} \mathrm{O}_{2}$ production was not being directed to lipid peroxidation, as indicated by the negative correlation (-0.79) observed between $\mathrm{H}_{2} \mathrm{O}_{2}$ and MDA (Figure 2A). According to Miller et al. (2008) ROS have a deleterious role to the plants, but some authors defend its role as a molecular indicator of environmental conditions, in particular in relation to $\mathrm{H}_{2} \mathrm{O}_{2}$. Under low temperature conditions, we observed an increase in the $\mathrm{H}_{2} \mathrm{O}_{2}$ content in the tolerant genotype, accompanied by increased MDA levels and CAT activity (Tables 2, 3, and 4). Although there was an increase in CAT activity, it was insufficient to eliminate excess $\mathrm{H}_{2} \mathrm{O}_{2}$. This result was confirmed by the -0.94 correlation observed between CAT activity and $\mathrm{H}_{2} \mathrm{O}_{2}$ content (Figure $3 \mathrm{~A}$ ). Similar results were obtained by Chakraborty and Bhattacharjee (2015), who when working with rice plants exposed to extreme temperatures $\left(8^{\circ}\right.$ and $\left.40^{\circ} \mathrm{C}\right)$, observed an increase in the $\mathrm{H}_{2} \mathrm{O}_{2}$ and MDA contents, accompanied by a reduction in CAT activity. Similarly, Zhang et al. (2015) observed that changes in SOD, peroxidase, and CAT activity and MDA content were not identical across saline and drought stress treatments in Magnaporthe grisea, suggesting that rice plant uses complex mechanisms in response to different stressors.

Regarding the sensitive genotype, there was a decrease in the $\mathrm{H}_{2} \mathrm{O}_{2}$ content under both stress conditions. Under saline stress, there was a significant increase in lipid peroxidation levels, whereas CAT activity changed little, which explains the negative correlation $(-0.22)$ observed between these variables (CAT activity and MDA) (Figure 2B). This can be explained by the low affinity CAT has for $\mathrm{H}_{2} \mathrm{O}_{2}$. According to Kotchoni and Gachomo (2006), when $\mathrm{H}_{2} \mathrm{O}_{2}$ is produced in chloroplasts, it is eliminated by APX, while $\mathrm{H}_{2} \mathrm{O}_{2}$ produced in the peroxisomes and glyoxysomes is removed by CAT. This specificity between enzymes and $\mathrm{H}_{2} \mathrm{O}_{2}$ reflects their different affinities, in that APX would have high affinity $(\mu \mathrm{M})$ and CAT low affinity $(\mathrm{mM})$ for $\mathrm{H}_{2} \mathrm{O}_{2}$. Therefore, CAT activity is only effective with relatively high concentrations of $\mathrm{H}_{2} \mathrm{O}_{2}$, which is why it is considered indispensable for ROS detoxification, particularly in conditions of severe stress when $\mathrm{H}_{2} \mathrm{O}_{2}$ levels are high (Dubey, 2011).

Under low temperature, the sensitive genotype responded differently to that observed under high salinity. When exposed to $13^{\circ} \mathrm{C}$, the plants exhibited a decrease in the $\mathrm{H}_{2} \mathrm{O}_{2}$ content but an increase in CAT activity, causing the lipid peroxidation levels to remain similar to those in the control treatment, suggesting that 'BRS Pampa' plants have good protection against oxidative damage in these conditions (Tables 2, 3, and 4). Similar results were obtained by Huang and Guo (2005), who found that increases in CAT activity were associated with responses to cold in rice genotypes. According to Gondim et al. (2012), increases in CAT activity are related to lower oxidative damage, emphasizing its protective function. There is growing evidence of the multiple roles that CAT plays in a variety of tissues at different stages of development, and its involvement in signal transduction pathways in response to several stressors (Fukamatsu et al., 2003; Verslues et al., 2007).

Plants contain several CAT isoforms that can directly dismutate $\mathrm{H}_{2} \mathrm{O}_{2}$, or oxidize substrates such as methanol, ethanol, formaldehyde, and formic acid (Breusegem et al., 
2001). In the tolerant genotype under saline stress, we found a negative correlation between OsCATC, OsCATA, and OsCATB and CAT activity (-0.35, -0.38 , and -0.70 , respectively) (Figure 1A). Although there was an increase in the expression levels of OsCATA and OsCATB, post-transcriptional changes or post-translational modifications may have inhibited a direct correlation between transcript levels and CAT activity. However, a strong correlation (0.85) was observed between OsCATA and OsCATB after 6 and $24 \mathrm{~h}$ of saline stress (Figure 1A). Yamane et al. (2010) also reported an increase in CAT activity that was related to OsCATB and OSCATC expression in tolerant rice genotypes under saline stress.

Under high salinity, OsCATA and OsCATC were the most responsive in the sensitive genotype, with expression levels that were higher than those observed in the tolerant genotype, which were accompanied by non-significant changes in CAT activity, resulting in a weak correlation between gene expression and enzymatic activity (CAT activity and OsCATA $=0.09$; CAT activity and $O S C A T C=0.02$ ) (Figure $1 \mathrm{~B}$ and $2 \mathrm{~B}$ ). Similar results were reported by Turan and Tripathy (2013), who also observed an increase in the transcript levels of OsCATA in rice genotypes that were tolerant and sensitive to high salinity; however, this was positively correlated with enzyme activity. Importantly, enzyme activity represents the cumulative effect of gene expression in different cellular compartments, and a reduction in the expression levels of other isoform genes that code the same enzyme can reduce the total enzyme activity (Ara et al., 2013).

Based on the gene expression results, we can infer that $O s C A T C$ may be a strong candidate as a molecular marker to differentiate between genotypes that are tolerant or sensitive to high salinity, because the sensitive genotype had expression levels that were below those of the control, whereas the tolerant genotype had RQ values that were 12.12 higher than those in the control. Under low temperature, OSCATA and OSCATB were the most responsive in both genotypes; however, the expression levels were higher in the sensitive genotype (Figure $1 \mathrm{C}$ and D). In contrast to what was observed under saline stress, in cold conditions, the increase in gene expression was accompanied by an increase in CAT activity, resulting in a stronger correlation between expression and enzymatic activity than that found with $\mathrm{NaCl}$ (Figures 2 and 3). Therefore, the data obtained in our experiment corroborate those of Chakraborty and Bhattacharjee (2015), who reported an increase in OsCATA expression in rice genotypes exposed to cold and heat.

Cis-elements work as molecular switches in response to stress, and are involved in the transcriptional regulation of a dynamic network of genes that control several biological processes, including responses to abiotic stress, hormones, and developmental processes (YamaguchiShinozaki and Shinozaki, 2005). We identified 36 common sequences in the promoter regions of the three CAT genes in 'BRS Bojuru' and 28 in 'BRS Pampa', which may not be involved in the differential expression responses observed between the genes (Figure 4).

OsCATA and OSCATB were the most responsive to saline and cold stress in 'BRS Bojuru', and we identified $11 \mathrm{cis}$-elements for this pair of genes, including ABRELATERD1 and WRKY71OS. ABRELATERD1 is related to ABRE (ABA responsive element) transcription factors, which are regulators of gene expression in response to several abiotic stressors, such as water deficit and freezing (Liao et al., 2008), while WRKY71OS is related to transcription factors belonging to the family WRKY, which are involved in several physiological functions, including plant defense against biotic and abiotic agents (Ulker and Somssich, 2004). Therefore, the presence of these cis-elements in the promoter regions of OsCATA and OsCATB may be associated with increases in the expression of these genes in response to low temperature or high salinity. According to Lata and Prasad (2011), although response pathways for different stressors normally operate independently, is it possible that there is some level of crosstalk among them.

Genetics and Molecular Research 15 (4): gmr15048977 
In both 'BRS Bojuru' and 'BRS Pampa', OsCATA and OsCATB were the most responsive to cold. In 'BRS Pampa', only four cis-elements that were common to the promoter regions were identified: AACACOREOSGLUB1, BIHD1, EECCRCAH1, and PYRIMIDINEBOXOSRAMY1A, which deserve special attention by future studies when investigating responses to low temperature conditions by rice plants. BIHD1 is the location of the connection between the transcription factor BELL and OsBIHD1, which is overexpressed in response to disease (Luo et al., 2005).

OsCATC responded differently in 'BRS Bojuru' and 'BRS Pampa' under highsalinity conditions. In 'BRS Bojuru', this gene was negatively regulated, with expression levels below or close to those in the control, whereas in 'BRS Pampa', it had high expression levels, particularly after 24 and $48 \mathrm{~h}$ of stress (RQ $=10.12$ and 12.12 , respectively). Twenty-five cis-elements that were identified in 'BRS Pampa' were not present in 'BRS Bojuru', including ANAERO2CONSENSUS and CBFHV. ANAERO2CONSENSUS is associated with genes that are responsive to anaerobic conditions, and CBFHV is associated with type dehydration responsive element-binding transcription factors, which are mainly involved in responses to osmotic stress (Xue, 2002; Mohanty et al., 2005). Interactions between cis-elements and transcription factors result in the activation or repression of gene expression in response to environmental factors or development. Therefore, studies that seek to identify cis-elements and transcription factors that are related to environmental stress would increase our understanding of the mechanisms of gene regulation, and plant responses to adverse environmental conditions. The sensitive genotype ('BRS Pampa') maintained a better balance between hydrogen oxyacid content, CAT activity, and lipid peroxidation under low temperature than the tolerant genotype ('BRS Bojuru'). In the tolerant genotype, OsCATA and OsCATB were the most expressive under high salinity and cold, OSCATA and OSCATC were the most responsive to high salinity, and $O S C A T A$ and $O S C A T B$ were the most responsive to cold.

OSCATC can be used to differentiate between genotypes with contrasting responses to high salinity, while OsCATB is the least useful in this regard; OsCATC is not recommended for distinguishing between tolerant and sensitive genotypes under low temperature. There was a positive correlation between CAT activity and OsCATB expression in the tolerant genotype under saline stress, and in the sensitive genotype under cold stress. Different $c i s$-elements were found for OsCATA, OsCATB, and OsCATC in both genotypes.

\section{Conflicts of interest}

The authors declare no conflict of interest.

\section{ACKNOWLEDGMENTS}

Research supported by the following Brazilian funding agencies: Coordenação de Aperfeiçoamento de Pessoal de Nível Superior (CAPES), Conselho Nacional de Desenvolvimento Científico e Tecnológico (CNPq), and Fundação de Amparo à Pesquisa do Rio Grande do Sul (FAPERGS).

Genetics and Molecular Research 15 (4): gmr15048977 


\section{REFERENCES}

Ara N, Nakkanong K, Lv W, Yang J, et al. (2013). Antioxidant enzymatic activities and gene expression associated with heat tolerance in the stems and roots of two cucurbit species ("Cucurbita maxima" and "Cucurbita moschata") and their interspecific inbred line "Maxchata". Int. J. Mol. Sci. 14: 24008-24028 http://dx.doi.org/10.3390/ijms141224008.

Ashraf M (2009). Biotechnological approach of improving plant salt tolerance using antioxidants as markers. Biotechnol. Adv. 27: 84-93 http://dx.doi.org/10.1016/j.biotechadv.2008.09.003.

Azevedo RA, Alas RM, Smith RJ and Lea PJ (1998). Response of antioxidant enzymes to transfer from elevated carbon dioxide to air and ozone fumigation, in the leaves and roots of wild-type and a catalase-deficient mutant of barley. Physiol. Plant. 104: 280-229 http://dx.doi.org/10.1034/j.1399-3054.1998.1040217.x.

Bradford MM (1976). A rapid and sensitive method for the quantitation of microgram quantities of protein utilizing the principle of protein-dye binding. Anal. Biochem. 72: 248-254. http://dx.doi.org/10.1016/0003-2697(76)90527-3

Breusegem FV, Vranová E, Dat JF and Inzé D (2001). The role of active oxygen species in plant signal transduction. Plant Sci. 161: 405-414 http://dx.doi.org/10.1016/S0168-9452(01)00452-6.

Chakraborty A and Bhattacharjee S (2015). Differential competence of redox-regulatory mechanism under extremes of temperature determines growth performances and cross tolerance in two indica rice cultivars. J. Plant Physiol. 176: 65-77 http://dx.doi.org/10.1016/j.jplph.2014.10.016.

Chinnusamy V, Zhu J and Zhu JK (2007). Cold stress regulation of gene expression in plants. Trends Plant Sci. 12: $444-$ $451 \mathrm{http} / / / \mathrm{dx}$. doi.org/10.1016/j.tplants.2007.07.002.

Dubey RS (2011). Metal toxicity, oxidative stress and antioxidative defense system in plants. In: Reactive oxygen species and antioxidants in higher plants (Gupta SD, ed.). Science Publishers, Enfield, UK.

Fukamatsu Y, Yabe N and Hasunuma K (2003). Arabidopsis NDK1 is a component of ROS signaling by interacting with three catalases. Plant Cell Physiol. 44: 982-989 http://dx.doi.org/10.1093/pcp/pcg140.

Gill SS and Tuteja N (2010). Reactive oxygen species and antioxidant machinery in abiotic stress tolerance in crop plants. Plant Physiol. Biochem. 48: 909-930 http://dx.doi.org/10.1016/j.plaphy.2010.08.016.

Gondim FA, Gomes-Filho E, Costa JH, Mendes Alencar NL, et al. (2012). Catalase plays a key role in salt stress acclimation induced by hydrogen peroxide pretreatment in maize. Plant Physiol. Biochem. 56: 62-71. PubMed http:// dx.doi.org/10.1016/j.plaphy.2012.04.012

Heath RL and Packer L (1968). Photoperoxidation in isolated chloroplasts. I. Kinetics and stoichiometry of fatty acid peroxidation. Arch. Biochem. Biophys. 125: 189-198 http://dx.doi.org/10.1016/0003-9861(68)90654-1.

Huang $\mathrm{M}$ and Guo Z (2005). Responses of antioxidative system to chilling stress in two rice cultivars differing in sensitivity. Biol. Plant. 49: 81-84 http://dx.doi.org/10.1007/s00000-005-1084-3.

Khare T, Kumar V and Kishor PB (2015). Na+ and Cl(-) ions show additive effects under $\mathrm{NaCl}$ stress on induction of oxidative stress and the responsive antioxidative defense in rice. Protoplasma 252: 1149-1165 http://dx.doi. org/10.1007/s00709-014-0749-2.

Komatsu S and Hossain Z (2013). Organ-specific proteome analysis for identification of abiotic stress response mechanism in crop. Front. Plant Sci. 4: 71 http://dx.doi.org/10.3389/fpls.2013.00071.

Kotchoni SO and Gachomo EW (2006). The reactive oxygen species network pathways:an essential prerequisite for perception of pathogen attack and the acquired disease resistance in plants. J. Biosci. 31: 389-404 http://dx.doi. org $/ 10.1007 / \mathrm{BF} 02704112$.

Lata C and Prasad M (2011). Role of DREBs in regulation of abiotic stress responses in plants. J. Exp. Bot. 62: 4731-4748 http://dx.doi.org/10.1093/jxb/err210.

Liao Y, Zou HF, Wei W, Hao YJ, et al. (2008). Soybean GmbZIP44, GmbZIP62 and GmbZIP78 genes function as negative regulator of ABA signaling and confer salt and freezing tolerance in transgenic Arabidopsis. Planta 228: 225-240 http://dx.doi.org/10.1007/s00425-008-0731-3.

Livak KJ and Schmittgen TD (2001). Analysis of relative gene expression data using real-time quantitative PCR and the 2(- $\Delta \Delta \mathrm{C}(\mathrm{T}))$ Method. Methods 25: 402-408 http://dx.doi.org/10.1006/meth.2001.1262.

Luo H, Song F, Goodman RM and Zheng Z (2005). Up-regulation of OsBIHD1, a rice gene encoding BELL homeodomain transcriptional factor, in disease resistance responses. Plant Biol (Stuttg) 7: 459-468 http://dx.doi. org $/ 10.1055 / \mathrm{s}-2005-865851$.

Mahajan S and Tuteja N (2005). Cold, salinity and drought stresses: an overview. Arch. Biochem. Biophys. 444: 139-158 http://dx.doi.org/10.1016/j.abb.2005.10.018.

Miller G, Shulaev V and Mittler R (2008). Reactive oxygen signaling and abiotic stress. Physiol. Plant. 133: 481-489 http://dx.doi.org/10.1111/j.1399-3054.2008.01090.x.

Mohanty B, Krishnan SP, Swarup S and Bajic VB (2005). Detection and preliminary analysis of motifs in promoters of anaerobically induced genes of different plant species. Ann. Bot. (Lond.) 96: 669-681 http://dx.doi.org/10.1093/aob/ $\underline{\operatorname{mci} 219}$.

Genetics and Molecular Research 15 (4): gmr15048977 
Moraes GP, Benitez LC, do Amaral MN, Vighi IL, et al. (2015). Evaluation of reference genes for RT-qPCR studies in the leaves of rice seedlings under salt stress. Genet. Mol. Res. 14: 2384-2398 http://dx.doi.org/10.4238/2015. March.27.24

Munns R and Tester M (2008). Mechanisms of salinity tolerance. Annu. Rev. Plant Biol. 59: 651-681 http://dx.doi. org/10.1146/annurev.arplant.59.032607.092911.

Qiu P (2003). Recent advances in computational promoter analysis in understanding the transcriptional regulatory network. Biochem. Biophys. Res. Commun. 309: 495-501 http://dx.doi.org/10.1016/j.bbrc.2003.08.052.

Singh RK, Redoña E and Refuerzo L (2010). Varietal improvement for abiotic stress tolerance in crop plants: special reference to salinity in rice. In: Abiotic stress adaptation in plants: physiological, molecular and genomics foundation (Pareek A, Sopory SK, Bohnert HJ and Govindjee, eds.). Springer Science and Business Media LLC, New York.

Turan S and Tripathy BC (2013). Salt and genotype impact on antioxidative enzymes and lipid peroxidation in two rice cultivars during de-etiolation. Protoplasma 250: 209-222 http://dx.doi.org/10.1007/s00709-012-0395-5.

Ulker B and Somssich IE (2004). WRKY transcription factors: from DNA binding towards biological function. Curr. Opin. Plant Biol. 7: 491-498 http://dx.doi.org/10.1016/j.pbi.2004.07.012.

Velikova V, Yordanov I and Edreva A (2000). Oxidative stress and some antioxidant systems in acid rain-treated bean plants: protective role of exogenous polyamines. Plant Sci. 151: 59-66 http://dx.doi.org/10.1016/S01689452(99)00197-1.

Verslues PE, Batelli G, Grillo S, Agius F, et al. (2007). Interaction of SOS2 with nucleoside diphosphate kinase 2 and catalases reveals a point of connection between salt stress and $\mathrm{H} 2 \mathrm{O} 2$ signaling in Arabidopsis thaliana. Mol. Cell. Biol. 27: 7771-7780 http://dx.doi.org/10.1128/MCB.00429-07.

Wang YC, Qu GZ, Li HY, Wu YJ, et al. (2010). Enhanced salt tolerance of transgenic poplar plants expressing a manganese superoxide dismutase from Tamarix androssowii. Mol. Biol. Rep. 37: 1119-1124 http://dx.doi.org/10.1007/s11033009-9884-9.

Weising K, Nybom H, Wolff K and Kahal G (2005). DNA fingerprinting in plants and fungi: principles, methods and applications. 2nd edn. CRC Press, London, UK.

Xue GP (2002). Characterisation of the DNA-binding profile of barley HvCBF1 using an enzymatic method for rapid, quantitative and high-throughput analysis of the DNA-binding activity. Nucleic Acids Res. 30: e77 http://dx.doi. org/10.1093/nar/gnf076.

Yamaguchi-Shinozaki K and Shinozaki K (2005). Organization of cis-acting regulatory elements in osmotic- and coldstress-responsive promoters. Trends Plant Sci. 10: 88-94 http://dx.doi.org/10.1016/j.tplants.2004.12.012.

Yamane K, Mitsuya S, Taniguchi M and Miyake H (2010). Transcription profiles of genes encoding catalase and ascorbate peroxidase in the rice leaf tissues under salinity. Plant Prod. Sci. 13: 164-168 http://dx.doi.org/10.1626/pps.13.164.

Yang J, Chen X, Zhu C, Peng X, et al. (2015). RNA-seq reveals differentially expressed genes of rice (Oryza sativa) spikelet in response to temperature interacting with nitrogen at meiosis stage. BMC Genomics 16: 959 http://dx.doi. org/10.1186/s12864-015-2141-9.

Yoshida S, Forno DA, Cock JH and Gomez KA (1976). Laboratory manual for physiological studies of rice. 3rd edn. International Rice Research Institutes, Manila, Philippines.

Zeng HW, Cai YJ, Liao XR, Qian SL, et al. (2010). Optimization of catalase production and purification and characterization of a novel cold-adapted Cat-2 from mesophilic bacterium Serratia marcescens SYBC-01. Ann. Microbiol. 60: 701708 http://dx.doi.org/10.1007/s13213-010-0116-2.

Zhang YP, e ZG, Jiang H, Wang L, et al. (2015). A comparative study of stress-related gene expression under single stress and intercross stress in rice. Genet. Mol. Res. 14: 3702-3717 http://dx.doi.org/10.4238/2015.April.17.20.

\section{Supplementary material}

Table S1. List of cis-elements in the promoter regions (1200 bp) of OsCATA, OsCATB, and OsCATC isoforms in 'BRS Bojuru'.

Table S2. List of cis-elements in the promoter regions (1200 bp) of OsCATA, OsCATB, and OsCATC isoforms in 'BRS Pampa'. 